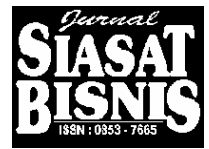

Hal.: $1-23$

\title{
BUDAYA: SUMBER KEKUATAN SEKALIGUS KELEMAHAN ORGANISASI
}

\author{
Achmad Sobirin \\ Fakultas Ekonomi \\ Universitas Islam Indonesia
}

\begin{abstract}
No longer after apprearing in Administrative Science Quarterly in 1979, the term "organizational culture" became a daily language among academicians manager, and business practioners. At that time they perceived that strong culture means good performance. Through the time however they realized that strong culture could also mean liabilties for an organization especially when the culture does not match the environment. That way in developing organizational culkture, adaptability should be taken into consideration so that culture become an asset really.
\end{abstract}

Key Word: Organizational culture, stromg culture, and weak culture.

\section{PENDAHULUAN}

Pada awal tahun 1980an, tidak lama setelah Administrative Science Quarterly memuat tulisan Andrew Pettigrew (1979) "On studying organizational cultures", budaya organisasi menjadi bahan pembicaraan sehari-hari berbagai kalangan, khususnya para praktisi bisnis, manajer dan akademisi. Lebih-lebih setelah buku-buku laris seperti In Search of Excellence (Peter and Waterman, Jr. 1982) beredar di pasaran, populeritas budaya organisasi semakin tinggi. Ketika itu diantara mereka seperti ada kesepakatan bahwa budaya organisasi merupakan sumber kekuatan baru dalam meningkatkan kinerja organisasi. Jika sebelumnya mereka hanya bertumpu pada perangkat keras organisasi (hard system tools) seperti strategi, struktur dan sistem, sejak itu mereka mulai yakin bahwa budaya organisasi juga memiliki peran yang tidak kalah penting.

Itulah sebabnya pada awal tahun 1980 an banyak perusahaan yang berlomba-lomba membangun budaya organisasi sebagai sarana untuk meningkatkan kinerjanya. Misi, visi, nilai-nilai perusahaan, tradisi, ritual dan upacara-upacara seremonial, yang sebelumnya tidak begitu dipedulikan karena dianggap tidak memiliki korelasi dengan kegiatan bisnis dan tidak memberi kontribusi terhadap peningkatan kinerja perusahaan lantas dijadikan bagian tidak terpisahkan dari kehidupan sehari-hari perusahaan. Tujuannya satu, demi membangun budaya yang kuat (strong culture) sebab seperti dituturkan Peter and Waterman, Jr. (1982), 
perusahaan yang berhasil adalah perusahaan yang memiliki budaya yang kuat. Diakatakannya bahwa faktor-faktor yang menyebabkan keberhasilan perusahaan antara lain: kedekatannya dengan konsumen, hands-on value driven, entrepreneuership, bentuk organisasi yang sederhana, tekun pada bisnis yang digeluti dsb. Jika pimpinan perusahaan dan semua karyawan mempunyai sense dan keyakinan yang sama (shared vision, values and belief) terhadap faktor-faktor ini maka dapat dipercaya bahwa perusahaan akan berhasil. Kesamaaan visi, nilai-nilai dan keyakinan diantara anggota organisasi menunjukkan kuatnya budaya perusahaan (strong culture) dan sebaliknya menunjukkan lemahnya budaya perusahaan (weak culture). Dengan kata lain, keberhasilan perusahaan dalam kaca mata Peter and Waterman Jr. ditentukan oleh kuat tidaknya budaya yang dimiliki perusahaan tersebut.

Dibandingkan para praktisi bisnis yang begitu antusias dalam membangun budaya organisasi, para akademisi tampaknya lebih hati-hati dan lebih rasional dalam menanggapi munculnya paradigma baru dalam mengelola organisasi ${ }^{1}$, apalagi setelah terbukti bahwa beberapa perusahaan yang semula dinyatakan Peter and Waterman Jr. berhasil karena budayanya kuat, ternyata kinerjanya tidak menggembirakan (lihat: Kerin, Mahajan and Varadarajan, 1990: 394-5). Kehati-hatian ini bukan berarti respon para akademisi terhadap kehadiran budaya organisasi sangat kecil, sebaliknya mereka justru terus melakukan penelitian tentang bagaimana seharusnya memahami budaya organisasi dan perannya dalam kehidupan organisasi. Itulah sebabnya dalam dua puluh tahun terakhir, penelitian tentang budaya organisasi terus berkembang (catatan: perkembangan bidang studi budaya organisasi akan dijelaskan pada bagian berikutnya.... Apa itu budaya organisasi?)

Uraian diatas pada dasarnya menegaskan bahwa selama ini sering terjadi salah kaprah, khususnya di kalangan para praktisi bisnis, dalam memahami makna budaya organisasi (lihat Achmad Sobirin, 1999). Kebanyakan beranggapan bahwa budaya organisasi selalu berdampak positif terhadap kehidupan organisasi, padahal dalam realita budaya sering menjadi variabel penghambat (Hofstede, 1997; Reger, et.al. 1998). Penyebabnya seperti dikatakan Morgan (1997) budaya organisasi yang terlalu kuat sering mendorong organisasi menjadi egosentrik, seolah-olah perusahaannya yang terbaik sehingga cenderung menyepelekan dan enggan mengakui keunggulan para pesaing. Jika demikian, sesungguhnya

\footnotetext{
${ }^{1}$ Sejak munculnya konsep budaya organisasi, sering dikatakan bahwa sejak tahun 1980an terjadi pergeseran dalam cara memandang organisasi dari memandang organisasi semata-mata sebagai living system ke organisasi sebagai budaya (lihat:: Smircich, 1983 dan Hawkin, 1997)
} 
budaya seperti dua sisi dari satu mata uang. Disatu sisi bisa menjadi asset bagi sebuah organisasi dan disisi lain bisa menjadi liability.

Berdasarkan penjelasan diatas, maka paper ini bermaksud mendiskusikan peran budaya didalam kehidupan organisasi baik peran positif maupun peran negatif. Lebih dari itu, karena peran negatif budaya sangat tidak diharapkan maka paper ini juga akan mendiskusikan bagaimana para manajer seharusnya mengelola budaya organisasi untuk menghindarkan dampak negatif budaya terhadap kehidupan organisasi. Oleh karenanya pada akhir paper ini akan didiskusikan pula strategi perubahan budaya. Untuk memfasilitasi semua itu diskusi akan dimulai dengan menjelaskan apa itu budaya organisasi dilanjutkan dengan penjelasan tentang elemen-elemen budaya dan proses terbentuknya budaya organisasi.

\section{APA ITU BUDAYA ORGANISASI?}

Kata "budaya" atau sering juga disebut "kultur" yang merupakan peng-Indonesiaan dari kata culture dalam bahasa Inggris atau cultuur dalam bahasa Belanda, sesungguhnya berasal dari bahasa Latin "colere" sebuah kata kerja yang berarti mengolah tanah, berladang atau bertani (Poespowardojo, 1989: 217-8). Namun ketika istilah ini digunakan para anthropolog, pengertiannya menjadi berubah. Misalnya, budaya diartikan sebagai way of life atau common way of life pandangan hidup yang berlaku bagi sekelompok masyarakat tertentu (Poepowardojo, ibid). Perubahan pengertian ini terjadi karena para anthropolog dalam memahami kegiatan pertanian tidak ditujukan pada apa yang dikerjakan para petani tetapi lebih pada bagaimana cara/pola mengerjakannya. Lebih dari itu, para anthropolog menggunakan istilah budaya tidak terbatas pada lingkup kegiatan pertanian saja tetapi juga melebar sampai pada kegiatan kemasyarakatan yang lain yang sifat kegiatannya ajeg, berulang-ulang dan bahkan pola yang sama berulang pada generasi berikutnya. Akibatnya budaya sering secara sederhana disebut sebagai tradisi yang berfungsi sebagai hukum (konvensi) bagi sekelompok masyarakat untuk bertindak, berprilaku dan berpandangan.

Karena keberadaan masyarakat (yang menjadi fokus perhatian para anthropolog) mengalami perkembangan yang semakin kompleks, maka pengertian budaya ternyata juga mengalami perkembangan, tidak sekedar sebagai way of life seperti tersebut diatas. Dalam monograf yang ditulisnya - Culture: A critical review of concepts and definitions, Kroeber and Kluckhohn (1952) misalnya menunjukkan tidak kurang dari 164 definisi budaya (pp. 42-56), diantaranya: 
1. Ruth Benedict: ..... that complex whole which include all habits acquired by man as a member of society (keseluruhan kehidupan manusia yang kompleks yang meliputi semua kebiasaan manusia yang diperolehnya sebagai bagian dari keanggotaannya dalam amsyarakat).

2. Malinowski: .....It (culture) obviously is the integral whole consisting of implements and consumers' goods, the constitutional charters for various social groupings, of human ideas and crafts, beliefs and customs (kultur adalah keseluruhan kehidupan manusia yang integral yang terdiri dari berbagai peralatan dan barang-barang konsumen, berbagai peraturan untuk kehidupan masyarakat, ide-ide dan hasil karya manusia, keyakinan dan kebiasan manusia).

3. Parsons: Culture ... consists in those patterns relative to behavior and the products of human action which may be inherited, that is, passed on from generation to generation independently of the biological genes (kultur terdiri dari suatu pola yang terkait dengan prilaku dan hasil tindakan manusia yang berlaku turun temurun dari satu generasi ke generasi berikutnya yang terpisah dari masalah keturunan).

Pengertian budaya yang bervariasi seperti tersebut diatas paling tidak menandakan dua hal (1) para anthropolog yang sesungguhnya mempunyai legitimasi untuk mendefinisikan budaya, tidak sepakat untuk memberi pengertian budaya secara baku, dan (2) tidak adanya kesepakatan tersebut sekaligus menegaskan bahwa realitas kehidupan manusia, yang menjadi pusat perhatian para anthropolog, tidak bisa dipahami secara linier dan partial, tetapi harus dipahami secara holistik dan polycular. Artinya aspek kehidupan manusia harus dipandang secara menyeluruh dan dari berbagai sudut pandang guna memahami dinamika kehidupan manusia. Perbedaan-perbedaan yang ada didalam masyarakat harus dipahami sebagai sesuatu yang wajar bukan sesuatu yang menggelisahkan. Sebab dari perbedaan-perbedaan tersebut kita justru menemukan adanya kesamaan-kesamaan dalam kehidupan manusia (Bartunek and Necochea, 2000).

Berbasis pada pemahaman bahwa budaya merupakan suatu pola kebiasaan yang berlaku pada sebuah masyarakat, dan disisi lain organisasi sering dianggap sebagai miniatur masyarakat², maka sesungguhnya organisasi juga mempunyai kebiasaan-kebiasaan yang sulit berubah. Itulah sebabnya para organization theorist kemudian beranggapan bahwa konsep budaya yang berlaku pada disiplin anthropologi juga bisa diterapkan pada

\footnotetext{
2 Dalam batas-batas tertentu organisasi tidak berbeda dengan sebuah masyarakat, karena organisasi adalah realitas sosial yang terdiri dari sekelompok orang yang bekerja berdasarkan struktur dan sistem, mempunyai tujuan dan mempunyai identifiable boundary (Daft, 1992).
} 
bidang studi organisasi3. Selanjutnya, seperti dijelaskan oleh Linda Smircich (1983: 342), keterkaitan antara konsep budaya dalam disiplin anthropologi dan konsep organisasi dalam disiplin teori organisasi yang menghasilkan tema-tema penelitian organisasi dan manajemen bisa dilihat pada gambar 1 sebagai berikut:

\section{Gambar 1.}

\section{Titik Singgung Antara Teori Organisasi Dan Budaya}

\begin{tabular}{|c|c|c|}
\hline Konsep Budaya dalam Disiplin Anthropologi & $\begin{array}{l}\text { Tema-tema Penelitian } \\
\text { Organiasi dan } \\
\text { Manajemen }\end{array}$ & $\begin{array}{l}\text { Konsep Organisasi dalam } \\
\text { Disiplin Teori Organisasi }\end{array}$ \\
\hline $\begin{array}{l}\text { Budaya adalah sebuah instrumen yang } \\
\text { berfungsi sebagai alat untuk melayani } \\
\text { kebutuhan-kebutuhan biologis dan psikologis } \\
\text { manusia (pendekatan functionalism) }\end{array}$ & & $\begin{array}{l}\text { Organisasi adalah instrumen } \\
\text { sosial yang didirikan untuk } \\
\text { menyelesaikan tugas-tugas } \\
\text { manusia (teori organisasi } \\
\text { klasik) }\end{array}$ \\
\hline & $\begin{array}{l}\text { Cross-culture } \\
\text { Atau } \\
\text { Comparative } \\
\text { management }\end{array}$ & \\
\hline $\begin{array}{l}\text { Budaya berfungsi sebagai mekanisme aturan } \\
\text { yang bersifat adaptif yang menyatukan } \\
\text { individu-individu kedalam sebuah struktur } \\
\text { sosial (pendekatan structural functionalism) }\end{array}$ & & $\begin{array}{l}\text { Organisasi adalah sebuah } \\
\text { organisme yang adaptif. } \\
\text { Keberadaannya terjadi karena } \\
\text { pertukarannya dengan } \\
\text { lingkungan eksternal (teori } \\
\text { organisasi kontingensi) }\end{array}$ \\
\hline $\begin{array}{l}\text { Budaya adalah kesadaran bersama yang } \\
\text { tersistem. Pola pikir manusia menghasilkan } \\
\text { budaya melalui sejumlah aturan (pendekatan } \\
\text { ethnoscience) }\end{array}$ & & $\begin{array}{l}\text { Organisasi adalah } \\
\text { pengetahuan yang tersistem. } \\
\text { Keberadaan organisasi } \\
\text { bergantung pada jaringan } \\
\text { makna subyektif yang pada } \\
\text { tingkatan tertentu dipahami } \\
\text { bersama oleh para anggotanya } \\
\text { dan muncul ke permukaan } \\
\text { dalam bentuk berbagai aturan } \\
\text { (pendekatan teori organisasi } \\
\text { kognitif) }\end{array}$ \\
\hline
\end{tabular}

${ }^{3}$ Meski konsep budaya organisasi baru berkembang mulai tahun 1980an, tetapi keterlibatan para anthropolog dalam studi organisasi sudah terjadi sejak Elton Mayo mengembangkan Human Relation School dengan proyek penelitian yang begitu terkenal "Hawthorne Study". Ketika itu dua anthropolog Malinowski dan Redcliff-Brown bergabung dengan proyek Mayo (lihat: Wright, 1997). 


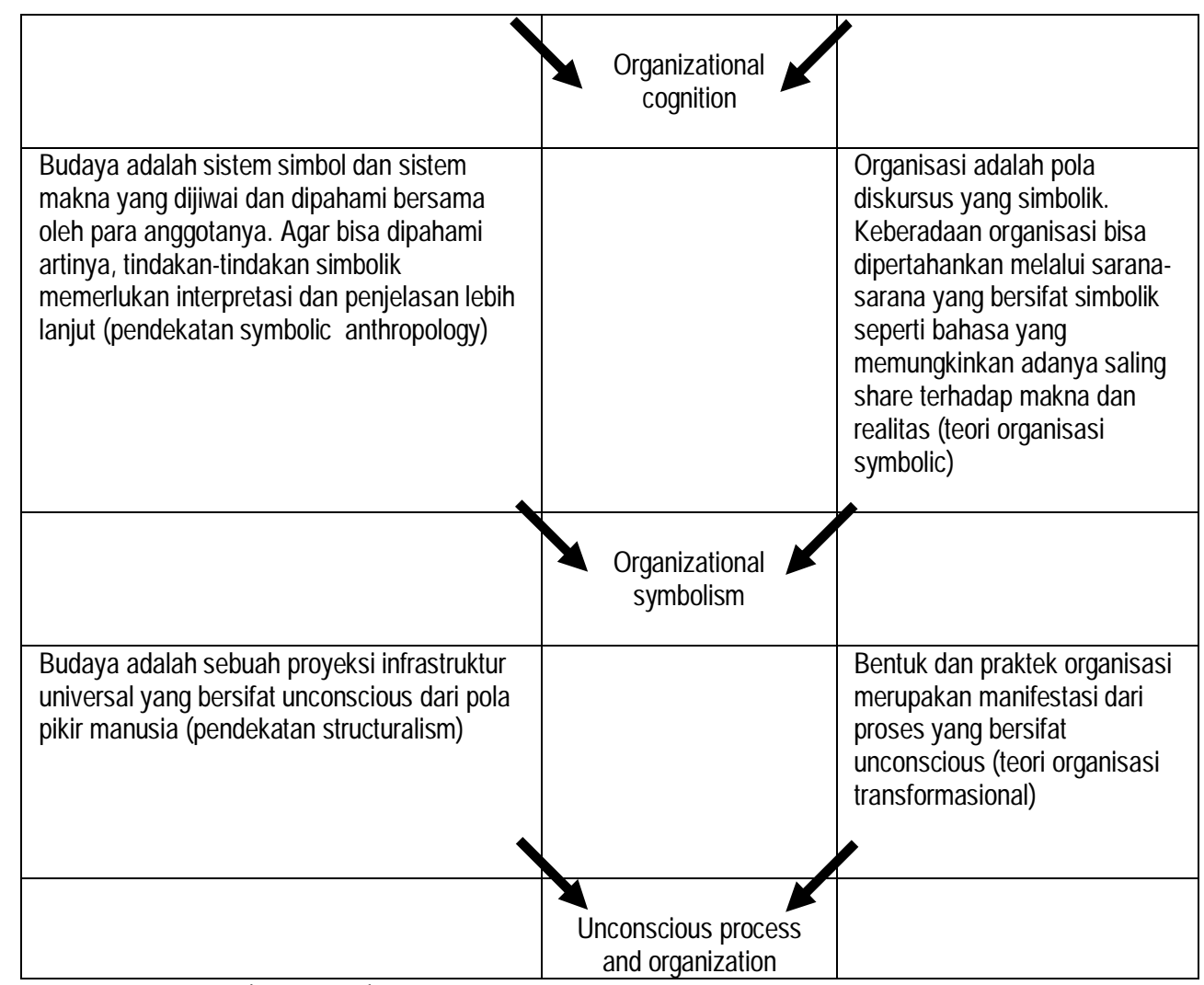

Sumber: Smircich (1983: 342)

Pada awalnya, seperti tampak pada gambar 1, persinggungan antara disiplin anthropologi dengan disiplin teori organisasi masing-masing dengan pendekatan functionalism yang dikembangkan oleh Malinowski dan teori organisasi klasik menghasilkan tema-tema penelitian lintas budaya atau perbandingan manajemen. Sedangkan tema penelitian yang menghasilkan konsep budaya organisasi yang menjadi fokus paper ini terjadi ketika pendekatan masing-masing adalah structural functionalism (Redcliff-Brown) dan teori organisasi kontingensi. Dengan konsep budaya organisasi, berarti organisasi dipandang sebagai instrumen sosial yang menhasilkan produk dan jasa serta menghasilkan produk sampingan berupa cultural artefacts seperti ritual, legenda dan upacara seremonial. Dengan demikian seperti halnya sebuah masyarakat, organisasi juga memiliki budaya - organization has culture dan sekaligus merupakan hasil kebudayaan - organization is a culture (Smircich, 1983). Artinya, bagi sebuah organisasi, budaya tidak lagi dianggap semata-mata sebagai variabel eksternal yang uncontrollable tetapi juga sebagai variabel internal organisasi yang manageble (Reichers and 
Schneider, 1990) dan menjadi bagian yang tidak terpisahkan dari kehidupan sehari-hari organisasi. Dari sinilah kemudian konsep budaya organisasi berkembang. Yang menjadi permasalahan sekarang adalah karena sejak semula para anthropolog tidak dapat memberikan pengertian baku tentang budaya, akibatnya hal yang sama juga terjadi ketika para teoritisi organisasi mencoba mendefinisikan pengertian budaya organisasi (Smircich, 1983). Andrew Pettigrew (1979: 574) misalnya, sebagai orang pertama yang secara resmi menggunakan istilah budaya organisasi, memberikan definisi budaya organisasi sebagai: "systems of... publicly and collectively accepted meanings operating for a given group at a given time". Pengertian ini mengindikasikan bahwa budaya organisasi merupakan sistem makna yang diterima secara terbuka dan kolektif yang digunakan dalam sekelompok orang tertentu pada satu waktu tertentu pula. Definisi-definisi lain dari mulai yang paling sederhana sampai yang kompleks diantaranya adalah sebagai berikut:

1. Deal and Kennedy (1982: 4) "the way we do things around here - cara kita melakukan sesuatu disini"

2. Hofstede (1980) "collective mental programming - pemrograman mental secara kolektif"

3. Davis (1984) "Budaya organisasi adalah pola keyakinan dan nilai-nilai yang dipahami dan dijiwai (shared) oleh anggota organisasi sehingga pola tersebut memberikan makna tersendiri bagi organisasi bersangkutan dan menjadi dasar aturan berperilaku didalam organisasi"

4. Schein $(1983,1984,1985,1990,1997)$ "Budaya adalah pola asumsiasumsi dasar yang digali, ditemukan dan dikembangkan oleh sekelompok orang ketika mereka belajar mengatasi masalah adaptasi ekternal dan integrasi internal, yang telah terbukti bisa berfungsi dengan baik dan oleh karenanya dianggap benar, sehingga pola tersebut diajarkan kepada anggota-anggota baru organisasi sebagai cara yang benar untuk memandang, berpikir dan bertindak dalam mengatasi masalah tersebut"

Pengertian diatas menunjukkan bahwa budaya organisasi adalah kebiasaan yang berlaku pada sebuah organisasi. Bisa jadi, dengan demikian, antara satu organisasi dengan organisasi lainnya mempunyai kebiasaan yang berbeda meski keduanya bergerak pada bidang aktivitas bisnis yang sama. Gambar 2 memberikan ilustrasi bagaimana Texas Instruments dan Hewlett Packard, dua perusahaan yang sama-sama bergerak di bidang elektronik mempunyai kebijakan dan orientasi yang berbeda yang dengan demikian kebiasaan dan budayanya pun berbeda.

Texas Instruments yang lebih berorientasi pada produksi massa dengan strategi low cost lebih menekankan pada pentingnya mengendalikan biaya sehingga orang-orang yang mempunyai kemampuan untuk itu seperti seorang insinyur dan seorang manajer yang concern terhadap masalah 
biaya memperoleh dukungan dan penghargaan lebih dari perusahaan. Secara kultural, dengan demikian Texas Instrument lebih berorientasi internal. Sebaliknya, Hewlett Packard secara kultural lebih berorientasi eksternal ${ }^{4}$. Orientasi ini didasarkan pada strategi yang diterapkannya yakni diferensiasi yang lebih mementingkan pengembangan keunikan produk baru. Dengan demikian orang-orang yang mampu mengembangkan produk baru dan mampu memasarkannya akan memperoleh penghargaan lebih. Akibat dari perbedaan oreientasi tersebut maka struktur organisasi, cara penilaian kinerja dan evaluasi diri masing-masing perusahaan juga berbeda. Disinilah kedua perusahaan mengembangkan budaya organisasi yang berbeda.

\section{Gambar 2.}

\section{Budaya Organisasi Texas Instruments dan Hewlett Packard}

\begin{tabular}{|c|c|c|}
\hline & TEXAS INSTRUMENTS & HEWLETT PACKARD \\
\hline $\begin{array}{l}\text { Ketrampilan karyawan } \\
\text { yang diharapkan dan } \\
\text { akan memperoleh } \\
\text { penghargaan lebih }\end{array}$ & $\begin{array}{ll}\square & \text { Engineering (Product and } \\
& \text { Process) } \\
\square & \text { Manufacturing } \\
\square & \text { Cost reduction management }\end{array}$ & $\begin{array}{ll}\square & \text { Product Development } \\
\square & \text { Marketing } \\
\square & \text { New product management }\end{array}$ \\
\hline $\begin{array}{l}\text { Peran manajemen } \\
\text { puncak dalam hal } \\
\text { strategi }\end{array}$ & $\begin{array}{ll} & \text { Strategis } \\
\square & \text { Resource allocation } \\
\square & \text { Global view }\end{array}$ & $\begin{array}{ll} & \text { People development } \\
\square & \text { Leadership on values } \\
\square & \text { Detail/tactical involvement }\end{array}$ \\
\hline Struktur organisasi & $\begin{array}{ll}\square & \text { Large production operation } \\
\square & \text { Integrated division } \\
\square & \text { Corporate level staff } \\
\end{array}$ & $\begin{array}{ll}\square & \text { Small operation unit } \\
\square & \text { Autonomous division } \\
\square & \text { Devision level staff } \\
\end{array}$ \\
\hline $\begin{array}{l}\text { Prosedur perencanaan } \\
\text { strategis }\end{array}$ & $\begin{array}{ll}\square & \text { Analysis by staff } \\
\square & \text { Evaluation of few big bets } \\
\square & \text { Rational, explicit, precise }\end{array}$ & $\begin{array}{ll}\square & \text { Analysis by line } \\
\square & \text { Screening of many small bets } \\
\square & \text { Subjective, implicit, imprecise }\end{array}$ \\
\hline $\begin{array}{l}\text { Evaluasi kinerja dan } \\
\text { cara-cara me motivasi } \\
\text { karyawan }\end{array}$ & $\begin{array}{ll} & \text { Individual evaluation } \\
\square & \text { Competitive (Internally) } \\
\square & \text { Winners may not Keep Earnings } \\
\square & \text { Short-term Reward (Bonuses) }\end{array}$ & $\begin{array}{ll} & \text { Team Evaluation } \\
\square & \text { Cooperative (Internally) } \\
\square & \text { Winning Team Keep Earnings } \\
\square & \text { Long-term Status (Stock } \\
\text { ownership) }\end{array}$ \\
\hline $\begin{array}{l}\text { Cara perusahaan } \\
\text { mengevaluasi dirinya }\end{array}$ & $\begin{array}{ll}\square & \text { Competitive Status (External) } \\
\square & \text { Organizational Innovativeness } \\
& \text { (Internal) } \\
\square & \text { Profits or Financial Return }\end{array}$ & $\begin{array}{ll}\square & \text { Organizational Helath (Internal) } \\
\square & \text { Technical Superiority (External) } \\
\square & \text { Long Term Capabilities }\end{array}$ \\
\hline
\end{tabular}

Sumber: Kerin, Mahajan and Varadarajan, 1990

\footnotetext{
4 Tentang dimensi-dimensi budaya organisasi, yang dalam contoh ini disebutkan sebagai berorientasi internal vs. berorientasi eksternal, lihat misalnya Reynolds, 1986; Achmad Sobirin, 1999.
} 
Perbedaan kebiasaan/budaya seperti tersebut diatas utamanya karena masing-masing organisasi memiliki collective mental programming yang berbeda (Hofstede, 1997) sehingga respon mereka, ketika menghadapi masalah yang sama, juga berbeda. Sekali kebiasaan ini terinteranalisasi kedalam diri para anggota organisasi dan terkristalisasi kedalam sistem organisasi yang mereka bangun bersama maka kebiasaan tersebut tidak mudah berubah. Kalau toh akhirnya harus berubah maka perubahannya terjadi secara gradual. Perubahan secara drastis masih dimungkinkan jika ada variabel eksternal yang memaksanya. Karena tidak mudah megalami perubahan akibatnya budaya organisasi sering dianggap sebagai karakteristik atau identitas diri organisasi (Sathe, 1985; Gagliardi, 1986; Wilkin, 1989; Balmer and Wilson, 1998; Gioia, Schulz and Corley, 2000).

\section{Gambar 3.}

\section{Perbedaan Karakteristik Pada Masing-Masing Fungsi Organisasi}

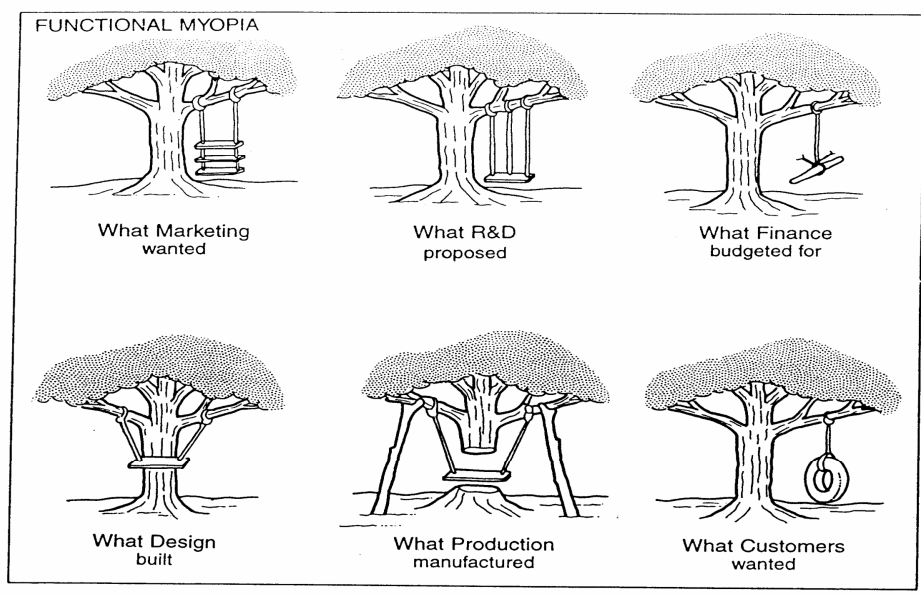

Sumber: Schneider and Barsoux (1997: 60)

Sesungguhnya perbedaan karakteristik tidak hanya terjadi pada dua organisasi yang berbeda seperti contoh diatas tetapi juga sangat dimungkinkan terjadi didalam satu lingkup organisasi, khususnya kalau organisasi tersebut cukup besar. Sebuah organisasi yang membagi aktivitasnya berdasarkan divisi atau fungsi organisasi memungkinkan masing-masing divisi atau fungsi organisasi tersebut memiliki karakteristik yang berbeda sebab secara natural kegiatan mereka berbeda dan tuntutan lingkungan yang dihadapinya juga berbeda. Schneider and Barsoux (1997) menyebut perbedaan ini sebagai functional myopia seperti tampak pada gambar 3.

Seperti tampak pada gambar 3 pula, masing-masing fungsi organisasi dianalogikan dengan sebuah pohon dimana setiap pohon mempunyai 
struktur yang berbeda. Fungsi pemasaran misalnya digambarkan dengan pohon yang memiliki anak tangga yang lebih banyak dibandingkan fungsi lainnya. Gambaran ini bisa diinterpretasikan bahwa fungsi pemasaran cenderung menghendaki kemudahan dalam mencapai sesuatu. Orangorang pemasaran umumnya tidak peduli jalan mana yang harus ditempuh. Bagi mereka yang penting adalah bagaimana harus cepat sampai tujuan. Artinya, bagi orang pemasaran biaya bukanlah fokus perhatian mereka, yang lebih diperhatikan adalah hasil atau efektifitasnya.

Berbeda dengan fungsi pemasaran, orang-orang yang bekerja pada departemen produksi cenderung lebih cost conscious karena penilaian kinerja mereka lebih ditekankan bagaimana bisa berhemat (efisien). Selain itu, orang-orang di fungsi produksi juga terbiasa pada suasana bising dan tempat kerja yang kotor, lebih berorientasi pada aktivitas, lebih cekatan, peduli terhadap persoalan-persoalan detail dan karena terbiasa bekerja dengan mesin maka pola prilakunya juga seperti mesin - serba teratur. Fungsi-fungsi lain, seperti diilustrasikan pada gambar 3 juga mempunyai karakteristik yang berbeda, termasuk keinginan konsumen yang cenderung lebih suka kenyamanan.

Walhasil, dari uraian diatas didapat kesimpulan sementara bahwa budaya organisasi adalah sebuah stereotype yang menggambarkan karakter umum sebuah kelompok, baik kelompok tersebut dibatasi oleh lingkup organisasi maupun oleh struktur organisasi dibawahnya. Jika lingkup stereotype tersebut adalah organisasi maka disebut budaya organisasi. Karena organisasi terdiri dari sub-sub organisasi (divisi/departemen) maka dari sudut pandang organisasi, stereotype yang terjadi pada lingkup yang lebih sempit dari organisasi (divisi/departemen) biasa disebut sub-budaya organisasi. Artinya menjadi hal yang biasa jika didalam sebuah organisasi terdapat beberapa sub-budaya (proses terbentuknya budaya/sub-budaya organisasi akan dijelaskan pada bagian lain tulisan ini). Atau seperti yang dijelaskan Jocano (1988: 23) budaya bukan merupakan hasil karya individual tetapi terjadi dalam sebuah grup, kelompok atau masyarakat.

\section{ELEMEN BUDAYA ORGANISASI}

Selain menegaskan bahwa budaya organisasi adalah kebiasaan yang berlaku pada sebuah organisasi, definisi diatas (lihat Davis, 1984; Schein, 1983) juga menjelaskan bahwa kebiasaan yang terjadi didalam sebuah organisasi sesungguhnya berasal dari sebuah sumber yakni nilainilai organisasi (organizational values). Itulah sebabnya, dilihat dari strukturnya, budaya organisasi terdiri beberapa komponen. Gambar 4 merupakan ringkasan tentang elemen budaya organisasi yang dikemukakan berbagai sumber. 
Gambar 4.

Elemen Budaya Organisasi Menurut Berbagai Sumber

\begin{tabular}{|c|c|c|c|c|c|}
\hline SUMBER & \multicolumn{5}{|c|}{ ELEMEN BUDAYA ORGANISASI } \\
\hline F. Landa Jocano $(1988,1990)$ & \multicolumn{3}{|c|}{ Idealistik } & \multicolumn{2}{|c|}{ Behavioral } \\
\hline Stanley Davis (1984) & & \multicolumn{2}{|c|}{ Guiding belief } & \multicolumn{2}{|c|}{ Daily belief } \\
\hline Geert Hofstede $(1980,1997)$ & & \multicolumn{2}{|c|}{ Nilai-nilai organisasi } & \multicolumn{2}{|c|}{ Praktik-praktik manajemen } \\
\hline Edgar Schein $(1985,1997)$ & $\begin{array}{l}\text { Asumsi } \\
\text { Dasar }\end{array}$ & \multicolumn{2}{|c|}{$\begin{array}{l}\text { Nilai-nilai } \\
\text { Oraanisasi }\end{array}$} & \multicolumn{2}{|c|}{ Artefak } \\
\hline Denise Rousseau (1990) & $\begin{array}{l}\text { Asumsi } \\
\text { Dasar }\end{array}$ & $\begin{array}{l}\text { Nilai-nilai } \\
\text { Organisasi }\end{array}$ & $\begin{array}{l}\text { Norma } \\
\text { Prilaku }\end{array}$ & $\begin{array}{c}\text { Prilaku } \\
\text { Organisasi }\end{array}$ & Artefak \\
\hline
\end{tabular}

Secara umum budaya organisasi terdiri dari dua elemen utama sebagaimana dikemukakan Jocano $(1988,1990)$ yaitu elemen yang bersifat idealistik dan elemen yang bersifat behavioral. Dikatakan idealistik karena elemen ini terselubung (elusive), tidak tampak ke permukaan (hidden) dan hanya orang-orang dalam organisasi saja yang tahu apa sesungguhnya ideologi mereka dan mengapa organisasi tersebut didirikan. Dalam bahasa yang agak berbeda, Davis (1984) menyebut elemen yang idealistik ini sebagai "keyakinan yang menjadi penuntun kehidupan seharihari sebuah organisasi" (guiding belief) dan Hofstede (1997) menyebutnya sebagai nilai-nilai organisasi (organizational values). Ketiganya (Jocano, Davis dan Hofstede) sepakat bahwa elemen yang bersifat idealistik ini merupakan inti dari budaya organisasi (core of culture).

Sementara itu Schein (1983) dan Rousseau (1990) mengatakan bahwa elemen yang idealistik tidak hanya terdiri dari nilai-nilai organisasi tetapi masih ada komponen yang lebih esensial yakni asumsi dasar (basic assumption) yang bersifat taken for granted (diterima apa adanya) dan unconscious (dilakukan diluar kesadaran) oleh karenanya tidak pernah dipersoalkan atau diperdebatkan keabsahannya. Bisa dikatakan bahwa asumsi dasar ini merupakan "postulate" bagi sebuah organisasi sehingga ketika seorang atau beberapa orang anggota organisasi melakukan sesuatu kemudian ditanya mengapa cara melakukannya demikian orang tersebut belum tentu bisa memberikan jawabannya karena apa yang mereka lakukan seakan-akan sudah diluar kesadarannya. Itulah sebabnya Schein dan Rousseau menganggap bahwa akar dari budaya organisasi bukan terletak pada nilai-nilai organisasi tetapi pada asumsi dasarnya.

Sedangkan elemen yang bersifat behavioral adalah elemen yang kasat mata, muncul ke permukaan dan tampak dalam prilaku sehari-hari para anggotanya. Oleh karenanya, bagi orang luar organisasi, elemen ini sering dianggap sebagai representasi dari budaya sebuah organisasi 
sebab elemen ini mudah diamati, dipahami dan diinterpretasikan. Itu sebabnya ketika orang luar oragnisasi mencoba mengidentifikasi budaya sebuah organisasi, maka yang bisa mereka lakukan (yang paling mudah) adalah dengan mengamati bagaimana para anggota organsiasi berprilaku dan kebiasaan-kebiasaan lain yang mereka lakukan. Itulah daily belief prakteik sehari-hari sebuah organisasi (Davis, 1984). Dalam bahasa Hofstede (1997), kebiasaan tersebut muncul dalam bentuk praktik-praktik manajemen - apakah sebuah organisasi lebih berorientasi pada proses atau hasil; lebih peduli pada kepentingan karyawan atau pekerjaan; lebih parochial atau profesional; lebih terbuka atau tertutup dan lebih pragmatis atau normatif (hal. 189-192). Sementara itu dua sumber terakhir mengatakan bahwa kebiasaan sehari-hari muncul dalam bentuk artefak termasuk didalamnya adalah prilaku para anggota organisasi. Artefak bisa berupa bentuk dan arsitektur bangunan, logo atau jargon, cara berkomunikasi, atau cara bertindak yang bisa dipahami oleh orang luar organisasi.

Secara umum bisa dikatakan bahwa kedua elemen budaya organisasi tersebut bukan elemen yang terpisah satu sama lain. Seperti dikatakan oleh Jocano keduanya merupakan satu kesatuan yang tidak terpisahkan sebab keterkaitan kedua elemen itulah yang membentuk budaya. Tetapi dilihat dari sensitifitasnya, elemen kedua (yang bersifat behavioral), lebih sensitif ketimbang elemen pertama. Penyebabnya adalah karena elemen kedua bersinggungan langsung dengan lingkungan eksternal organisasi sehingga ketika budaya sebuah organisasi terpaksa harus berubah karena desakan lingkungan maka biasanya yang pertama kali berubah adalah elemen kedua, sedangkan elemen pertama jarang mengalami perubahan karena letaknya yang terselubung. Tetapi karena budaya tidak tanpa perubahan (Hatch, 1993) dan elemen pertama terpaksa harus berubah maka perubahan biasanya terjadi secara struktural (Harris and Ogbonna, 1998). Untuk penjelasan tentang perubahan budaya organisasi, lihat juga Achmad Sobirin (2001b, segera terbit). Dari penjelasan diatas, Rosseau (1990) menggambarkan elemen budaya organisasi layaknya sebuah bawang dimana kulit luarnya (elemen yang bersifat behavioral) mudah mengelupas sedangkan isinya (core of culture) tidak mudah berubah.

\section{PROSES TERBENTUKNYA BUDAYA ORGANISASI}

Sesuai dengan asal katanya, organisasi berasal dari bahasa Yunani "organon" sebuah kata kerja yang berarti alat bantu (lihat Morgan, 1997). Jadi yang dimaksud dengan organisasi adalah alat bantu manusia yang sengaja didirikan untuk membantu manusia mencapai tujuan-tujuannya. Dengan demikian, ketika seseorang atau sekelompok orang mendirikan sebuah organisasi, mereka mendirikannya bukan tidak disengaja dan bukan 
tanpa alasan. Masing-masing mempunyai alasan tersendiri mengapa organisasi tersebut perlu didirikan. Berbekal alasan tersebut, para pendiri kemudian menyediakan fasilitas, dana dan merekrut orang lain yang sepaham dengannya untuk dijadikan karyawan dan ditempatkan pada posisiposisi tertentu sehingga kegiatan sebuah organisasi bisa berjalan sebagaimana mestinya. Disamping itu, mereka juga meletakkan dasar filososfi organisasi, menentukan arah kebijakan organisasi dan menjadi inisiator dalam pengembangan organisasi dimasa datang. Bagi sebuah organisasi yang baru berdiri, dengan demikian, peran para pendiri begitu sentral. Hitam putihnya organisasi berada di tangan mereka.

Karena orang-orang yang berada dalam organisasi masih relatif baru dan belum mempunyai pengalaman dalam menyelesaikan berbagai masalah, baik masalah adaptasi eksternal maupun integrasi internal maka semua yang dilakukan para pendiri diatas pada akhirnya menjadi tuntunan bagi para anggota baru organisasi dalam cara memandang dan menyelesaikan masalah yang dihadapi organisasi, cara berprilaku, dan cara bertindak. Ketika tuntunan tersebut terinternalisasi kedalam diri masingmasing anggota dan tersistem kedalam organisasi secara keseluruhan, dipahami dan dijiwai bersama maka dari sinilah kemudian terbentuk budaya organisasi. Jadi, seperti dikatakan oleh Schein (1983), peran para pendiri dalam proses pembentukan budaya, khususnya bagi organisasi yang baru pertama berdiri, sangat besar. Bisa dikatakan bahwa mereka (para pendiri) menjadi satu-satunya sumber terbentuknya budaya dalam sebuah organisasi. Implikasinya, karena pembentukan budaya berasal dari satu sumber, maka budaya yang terbentuk lebih bersifat monolitik.

Namun ketika organisasi sudah semakin besar dan kegiatannya semakin kompleks, estafeta kepemimpinan umumnya diserahkan kepada seorang manajer profesional, sedangkan para pendiri bertindak sebagai pengawas yang terlibat dalam kehidupan organisasi secara tidak langsung. Sekarang berarti kendali organisasi, termasuk proses pembentukan dan mempertahankan budaya organisasi, bergeser dari para pendiri ke para manajer profesional. Meski pergantian kepemim-pinan ini tidak berdampak terhadap perubahan landasan filosofis organisasi, bukan tidak mungkin pimpinan yang baru (manajer profesional)) melakukan interpretasi ulang terhadap filosofi organisasi (Harris and Ogbonna, 1998). Hal ini terjadi utamanya jika terjadi perubahan lingkungan eksternal yang memaksa organisasi harus menyesuaikan dirinya.

Jika interpretasi ulang ini menjadikan organisasi sukses, selanjutnya nilai-nilai baru ini dikomunikasikan kepada seluruh anggota organisasi, dishared dan dipertahankan untuk menjadi nilai-nilai bersama. Proses pembentukan dan mempertahankan budaya semacam ini disebut sebagai "virtuous circle". Sebaliknya, jika pembentukan nilai-nilai bersama ini gagal 
maka ada dua kemungkinan yang terjadi. Kemungkinan pertama adalah kembali kepada nilai-nilai lama yang selama ini telah menjadi panutan (guiding belief), dan kemungkinan kedua adalah para anggota organisasi berupaya membentuk nilai-nilai baru lain yang cocok dengan kebutuhan mereka. Dari kemungkinan kedua inilah terjadi deviasi dari budaya lama ke budaya baru. Proses deviasi seperti ini disebut "vicious circle" (untuk penjelasan ini lihat misalnya: Gagliardi, 1986; Hampen-Turner, 1994) dan merupakan awal terbentuknya sub-kultur yang menjadi embrio terbentuknya budaya baru. Gambar 5 menunjukkan bagaimana virtuous circle berubah menjadi vicious circle dan menjadi virtuous cirle baru.

\section{Gambar 5.}

Proses terbentuknya budaya organisasi

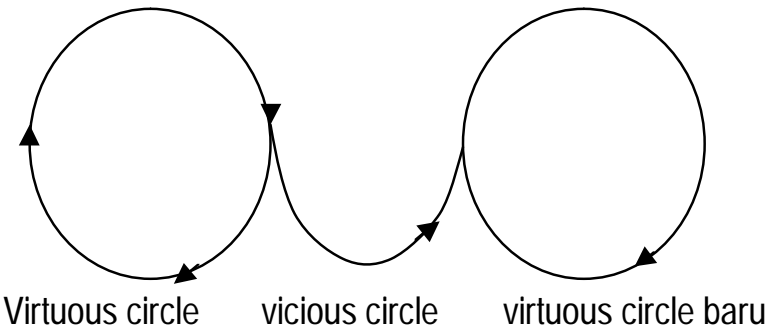

Seperti terlihat pada gambar 5 , tarik menarik antara virtuous dan vicious circle terus berlangsung sejalan dengan perkembangan organisasi. Semakin organisasi berkembang, vicious circle akan selalu muncul yang akan dipertahankan pada virtuous circle baru dan diikuti pula oleh vicious circle yang lain. Proses semacam ini memungkinkan terbentuknya sub-sub budaya dan bahkan budaya baru dalam sebuah organisasi. Akibatnya menjadi hal yang biasa jika sebuah organisasi besar memiliki lebih dari satu macam budaya, sekali lagi, meski kadang-kadang asumsi dasar dan nilai-nilai organisasi tidak berubah.

Ada beberapa alasan mengapa dalam sebuah organisasi terbentuk lebih dari satu macam budaya (1) meski organisasi didirikan oleh seseorang atau sekelompok orang yang se-ide dan mempunyai kesamaan tujuan, individu-individu yang masuk belakangan berasal dari berbagai latar belakang yang berbeda baik dalam hal pendidikan, kepribadian, maupun keluarga (Jocano, 1990). Perbedaan latar belakang ini merupakan awal dari perbedaan budaya dalam organisasi sebab masing-masing individu menpunyai "mindset" atau dalam bahasa Hofstede, mental programming yang berbeda, (2) Bolon and Bolon (1994) menegaskan bahwa individuindividu didalam organisasi tidak semata-mata sebagai obyek yang hanya meneruskan budaya yang diciptakan oleh para pendiri dan pimpinan pucak 
organisasi sebagaimana dijelaskan oleh Schein, tetapi juga sebagai subyek yang sekaligus bisa menciptakan budaya tersendiri dan (3) meski masingmasing organisasi mempunyai karakteristik tersenidiri, organisasi merupakan bagian dari sistem sosial yang ada di masyarakat. Artinya, interaksi antar individu dalam organisasi dan interaksi mereka dengan dunia luar akan selalu terjadi. Interaksi ini menyebabkan terjadinya akulturasi dan enkulturasi. Dalam skala yang lebih besar, budaya organisasi merupakan bagian dari budaya industri, budaya regional, budaya nasional maupun internasional. Sementara itu dalam skala yang lebih kecil, di dalam budaya organisasi dapat muncul pula budaya profesional maupun budaya fungsional (Schneider and Barsoux, 1997; Bloor and Dawson, 1994). Jadi, persinggungan antara budaya organisasi dengan budaya-budaya yang lain merupakan sesuatu yang tidak terhindarkan.

Oleh sebab itu jika penjelasan diatas dijadikan patokan, maka (1) dapat dikatakan bahwa sebuah organisasi bisa mempunyai bermacam budaya, khususnya jika organisasi tersebut cukup besar baik karena luasnya wilayah geografi, jumlah karyawan, banyaknya divisi/departemen, maupun karena perbedaan jenis usaha dan komposisi karyawannya. Paham ini paling tidak dianut oleh Barley (1983), Gregory (1983), Martin and Siehl (1983) dan Riley (1983). Bagi mereka, kultur terbentuk dalam sebuah group dan karena dalam sebuah organisasi terdiri dari beberapa group maka bisa jadi dalam sebuah organisasi akan terbentuk pula beberapa subkultur dan (2) seperti dikatakan oleh Hach (1993) karena dalam sebuah organisasi selalu terjadi akulturasi dan enkulturasi maka budaya organisasi lebih bersifat dinamis.

\section{BUDAYA ORGANISASI: ASSETS DAN LIABILITIES}

Pada saat-saat awal populeritas budaya organisasi, pelaku bisnis, akademisi dan para teoritisi organisasi begitu yakin bahwa budaya organisasi merupakan variabel kunci yang bisa mendorong keberhasilan perusahaan. Meski tidak sepenuhnya benar, dimuka telah dijelaskan bahwa perusahaanperusahaan yang berhasil ternyata mempunyai budaya yang kuat - strong culture (Peter and Waterman Jr., 1982). Bagi Denison (1990) dan Kotter and Heskett (1992), perusahaan yang berhasil bukan sekedar mempunyai budaya yang kuat tetapi budaya yang kuat tersebut harus cocok dengan lingkungannya.

Penjelasan diatas menegaskan bahwa adaptability merupakan variabel penting yang perlu diperhatikan dalam menjelaskan makna budaya organisasi bagi keberhasilan organisasi. Seperti yang dikatakan Robbins (1997), hal ini didasarkan pada suatu kenyataan bahwa hubungan antara budaya dengan kinerja perusahaan bersifat modest (tidak terlalu kuat) sehingga 
perlu moderating variable untuk memperjelas sejauh mana kontribusi budaya organisasi terhadap kinerja perusahaan. Artinya, budaya organisasi bukan satu-satunya variabel yang dapat mempengaruhi kinerja perusahaan. Dalam hal ini Bate (1994), O'Reilley (1989) dan Wilkin and Ouchie (1983) mengatakan bahwa "budaya sebagai perangkat lunak organisasi harus kompatibel dengan perangkat kerasnya" manajemen strategi. Hubungan antara budaya organisasi dan strategi perusahaan dijelaskan oleh Davis (1984) seperti tampak pada gambar 6.

Perlunya kompatibilatas ini sekali lagi menunjukkan bahwa budaya organisasi tidak bisa berdiri sendiri. Hal inilah yang mendorong Lim (1995: 19) berkesimpulan bahwa hubungan budaya - kinerja bukan bersifat kausalitas dimana budaya organisasi bisa digunakan untuk memprediksi kinerja perusahaan. Budaya organisasi dalam pandangan Lim lebih berfungsi sebagai alat untuk mendeskripsikan dan menjelaskan apa yang terjadi dalam perusahaan dalam rangka memahami perusahaan tersebut lebih baik.

Terlepas dari minimnya peran budaya organisasi sebagai prediktor kinerja perusahaan, budaya organisasi bisa berfungsi sebagai perekat (glue) yang membentuk kohesivitas (Schein, 1985; Smircich, 1983) dan semangat (morale) para anggota organisasi (Siehl and Martin, 1990). Juga sebagai social control yang mendorong semua anggota organisasi mempunyai komitmen terhadap kemajuan organisasi (O'Reilley, 1989) sehingga tidak terjadi organizational drift seperti dikhawatirkan oleh Barlett and Ghosal (1994, 1995) dan Ghosal and Barlett (1995). Kekhawatiran ini beralasan mengingat organisasi itu sendiri terdiri dari beberapa individu yang berasal dari berbagai latar belakang dan masing-masing individu mempunyai tujuan yang bukan tidak mungkin berbeda dengan tujuan organisasi (Jocano, 1990).

\section{Gambar 6.}

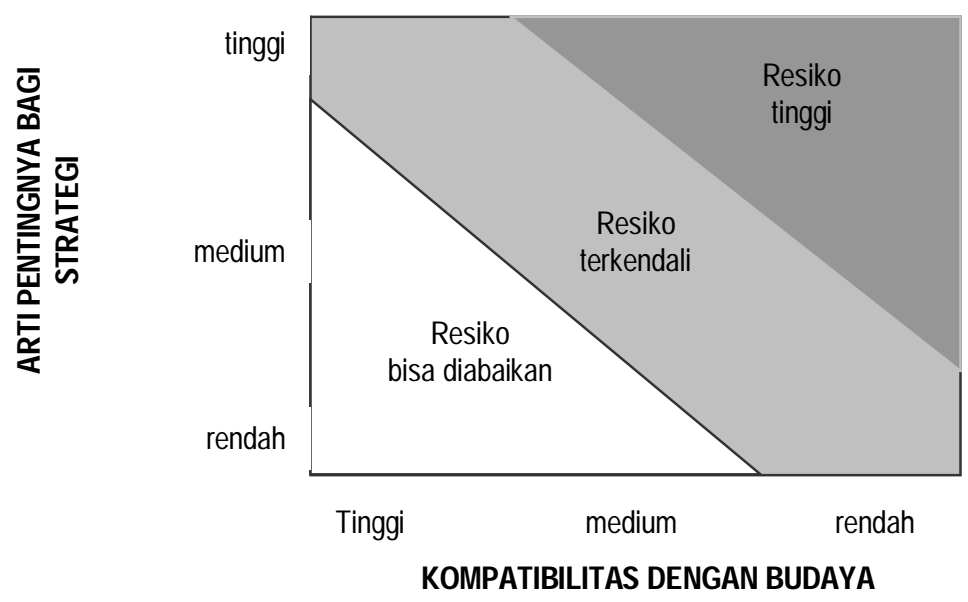


Pendek kata, dalam konteks pengembangan organisasi, memahami makna budaya organisasi dianggap sangat relevan. Jadi dalam hal ini budaya organisasi bisa dianggap sebagai assets. Paling tidak budaya organisasi berperan sebagai alat untuk melakukan integrasi internal (Paine, 1994). Jika peran ini bisa berfungsi dengan baik dan dibarengi oleh penyusunan strategi yang tepat maka bisa diharapkan kinerja organisasi akan meningkat. Hal ini sejalan dengan yang diungkapkan oleh Paul Bate (1994) "soft systems means hard systems" dan "hard systems means soft systems". Artinya kompatibilitas soft system dan hard system tidak bisa dihindarkan jika perusahaan menginginkan kinerjanya meningkat.

Uraian diatas memberi kesan bahwa budaya organisasi selalu mempunyai dampak positif terhadap kehidupan organisasi. Dalam praktik sering terjadi yang sebaliknya, budaya organisasi justru menjadi faktor penghambat dalam kehidupan organisasi (budaya dianggap sebagai liabilities). Gagalnya privatisasi, merger dan akuisisi (A. Sobirin, 2000, 2001a) dan terus menurunnya kinerja organisasi, bukan tidak mungkin karena organisasi tersebut mempunyai budaya yang terlampau kuat. Pasalnya, budaya yang terlalu kuat bisa menimbulkan egosentrisme (Morgan, 1997:256) seolah-olah dirinya yang terbaik diantara para pesaing. Sindrome seperti ini biasanya terjadi manakala kinerja perusahaan terus menerus membaik (Reger, et al. 1994), namun disisi lain mereka tidak menyadari jika lingkungan telah berubah (Kotter and Heskett, 1992). Kondisi ini bisa disebut sebagai cultrural trap - jebakan kultural. Artinya para pengelola organisasi tidak menyadari bahwa kultur menjadi dysfunctional bagi kehidupan organisasi. Contoh klasik tentang hal ini ditemukan pada kasus IBM yang sampai dengan tahun 1970an menguasai pasar komputer tetapi ambruk selama tahun 1980an dan baru bangkit kembali setelah beberapa kali mengalami penggantian CEO dan perubahan budaya.

Untuk menghindari kekhawatiran Morgan, menurut Gioia, Schultz and Corley (2000) perlu dibedakan antara istilah enduring identity (identitas organisasi yang dari waktu ke waktu yang berarti pula budaya yang kuat tidak berubah) dengan an identity having continuity (sebuah identitas yang bisa bertahan lama). Pada istilah pertama - enduring identity, identitas organisasi cenderung bersifat permanen dari waktu ke waktu dan statis tanpa mengalami perubahan meski terjadi perubahan lingkungan. Contoh klasik tentang hal ini misalnya dapat ditemui pada kasus IBM yang terlalu kaku dalam menginterpretasikan identitasnya "respect to individuals" yang mengakibatkan kinerja perusahaan mengalami penurunan selama tahun 1980an. Sedangkan yang dimaksud dengan istilah kedua identity having continuity, identitas/budaya organisasi harus diinterpretasikan dan diberi makna secara berbeda sesuai dengan tuntutan perubahan lingkungan (bersifat kontektual) sementara nilai-nilai dan keyakinan inti organisasi 
masih tetap dipertahankan. Atau dengan kata lain, pemaknaan terhadap identitas/budaya organisasi harus bersifat dinamik (Hatch, 1993). Misalnya, untuk mencapai kondisi seperti sekarang, identitas Hewlett Packard yang bersumber pada nilai-nilai inti "H-P way" terus mengalami reinterpretasi tanpa harus meninggalkan nilai-nilai inti tersebut (lihat Collins and Porras, 1996).

PENUTUP

Bisa dikatakan bahwa apa yang disajikan dalam paper ini tidak ada sesuatu yang baru dalam mendiskusikan konsep budaya organisasi. Pesan yang barangkali ingin disampaikan adalah hendaknya kita berhati-hati dalam memahami konsep budaya organisasi yang masih relatif baru (Reichers and Schneider, 1990) yang baru berkembang selama dua puluh tahun terakhir. Oleh karenanya dalam mendesain budaya bagi sebuah organisasi hendaknya jangan sampai menimbulkan cultural trap. Artinya assesment terhadap eksistensi budaya dalam sebuah organisasi hendaknya selalu dilakukan agar budaya tersebut match dengan strategi dan kebutuhan lingkungan dimasa datang.

\section{DAFTAR PUSTAKA}

Achmad Sobirin, 1997, Organizational Culture: Konsep, Kontroversi, Dan Manfaatnya Untuk Pengembangan Organisasi, Jurnal Akuntansi dan Auditing Indonesia, Vol 1 no 2. Hal. 152-173

Achmad Sobirin, 1999, Memahami Arti dan Makna Budaya Organisasi, Jurnal Sinergi, Magister Manajemen UII, Vol. 2 no. 2, halaman 189-215

Achmad Sobirin, 2000, Privatisasi: Implikasinya Terhadap Perubahan Prilaku Karyawan Dan Budaya Organisasi, Jurnal Siasat Bisnis, no. 5 vol. 1, halaman 25-48.

Achmad Sobirin, 2001, Merger dan Akuisisi: Sebuah Perkawinan Paradosal, Jurnal Siasat Bisnis, (segera terbit)

Adizes, Ichak, 1999, Managing Corporate Life Cycles, New Jersey, Prentice Hall Press.

Barlett, C.A and S. Ghoshal (1994), Changing The Role Of Top Management: Beyond Strategy To Purpose, Harvard Business Review, November-December, pp. 79-88 
Barlett, C.A and S. Ghoshal (1995), Changing The Role Of Top Management: Beyond Sysyems To People, Harvard Business Review, May-June, pp. 132-142

Bartunek, J.M. and R.A. Necochea, 2000, Old Insights And New Times: Kairos, Inca Cosmology, And Their Contributions To Contemporary Management Inquiry, Journal Of Management Inquiry, pp. 103-112

Bate, P. (1994), Strategies For Cultural Change ${ }_{1}$ Oxford: Butterworth Heinemann.

Benedict, R. (1971), Encyclopedia Americana, Vol. 8

Bolon, D.S. and D.S. Bolon (1994), Roconceptualization And Analysis Of Organizational Culture, Journal Of Managerial Psychology, Vol. 9 no. 5. Pp. 22-27

Bloor, G. and P. Dawson (1994), Understanding Professional Culture in Organizational Context, Organization Studies, Vol. 15 no. 2, pp. $275-295$

Caveleri, S. and K. Obloj (1993), Management System: A Global Perspective ${ }_{\llcorner}$Belmont CA: Wadsworth Publishing Company.

Collins, J.C and J.I. Poras, 1996, Building Your Company's Vision, Harvard Business Review, September-October, pp. 65-77

Daft, R.L. (1992), Organization Theory And Design, $4^{\text {th }}$ Edition, Singapore: Info Access Distribution Ltd.

Davis, S. (1984), Managing Corporate Culture ${ }_{1}$ Cambridge MA: Belinger

Deal, T.E. and A.A. Kennedy (1982), Corporate Culture ${ }_{1}$ Addison-Wesley

Denison, D.R. (1990), Corporate Culture And Organizational Effectiveness, New York: John Wiley and Son

Enz, C.A. 1986, Power And Shared Values In The Corporate Culture, Annarbor Michigan: UMI research press.

Fletcher, B. and F. Jones (1992), Measuring Organizational Culture: The Cultural Audit, Managerial Auditing Journal, 7(6), pp. 30-36

Gagliardi, P. (1986), The Creation And Change Of Organizational Culture: A Conceptional Framework, Organization Studies_Vol. 7, no. 2, pp.119-134

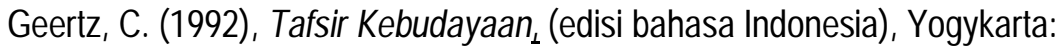
Kanisius 
Ghoshal, S. and C.A. Barlett (1995), Changing The Role Of Top Management: Beyond Structure To Process, Harvard Business Review, January-February, pp. 86-96.

Gioia, D.A., M. Schulz and K.G. Corley, 2000, Organizational Identity, Image And Adaptive Instability, Academy Of Management Review, pp. $63-81$

Hampen-Turner, C., 1994, Corporate culture, London: Piatkus Publisher.

Harris, L.C, and E. Ogbonna (1998), Employee Responses To Cultural Change Efforts, Human Resource. Management Journal, Vol. 8 No. 2, pp. 78-92.

Hatch, J.M. (1993), The Dynamics Of Organizational Culture, Academy Of Management Review, October, Vol. 18, no. 4, pp. 657-693.

Hawkin, P. (1997), Organizational culture: Sailing Between Evangelism And Complexity, Human Relation, April, Vol. 50, no. 4, pp. 417-440.

Hofstede, G. (1980), Cultural Consequences: International Difference In Work Related Values, Beverly Hill, CA: Sage Publication

Hofstede, G. (1997), Cultures And Organizations: Sofware Of The Mind, New York: McGraw Hill

Hofstede, G. (1998a), Attitude, Values And Organizational Culture: Disentangling The Concepts, Organization Studies, Vol. 19, no. 3, pp. 477-492.

Hofstede, G. (1998b), Identifying Organizational Subcultures: An Empirical Approach, Journal Of Management Studies. January; Vol. 35, no. 1, pp. 1-12

Hofstede, G., B. Neuijen, D. Ohayev, and G. Sanders, 1990, Measuring Organizational Culture: A Qualitative And Quantitative Study Across Twenty Cases, Administrative Science Quarterly, June, pp. 286-318

Jocano, F.L. 1988, Toward Developing Filipino Corporate Culture,_Metro Manila: Punlad Research House

Jocano, F.L. 1990, Management By Culture ${ }_{\perp}$ Metro Manila: Punlad Research House

Jones, G. R. 1995, Organizational Theory: Text And Cases, Reading MA: Addison-Wesley 
Kerin, R.A., V. Mahajan and P.R.Varadarajan (1990), Contemporary Perspectives On Strategic Market Planning, Boston: Allyn and Bacon.

Kluckhohn, F. and F. Strodtbeck (1961), Variation In Value Orientation, Wesport, CT: Greenwood Press

Kroeber, A.L. and C. Kluckhohn (1952), Culture: A Critical Of Concept And Definisions, Cambridge: Peabody Museum.

Kotter, J.P. and J.L. Heskett (1992), Corporate Culture And Performance, New York: The Free Press

Lane, H.W. and J.J. DiStefano (1992), International Management Behavior, $2^{\text {nd }}$ Edition, Boston: PWS-Kent Publishing Company.

Leadford, G.E. Jr., J.R. Wendenhof and J.T. Strahley, 1995, Realizing a Corporate Philosophy, Organization Dynamics, Winter, pp. 4-19

Lim, B. (1995), Examining The Organizational Culture And Organizational Performance Link, Leadership And Organizational Development Journal, Vol. 16, no. 5, pp. 16-21.

Martin J. and C. Siehl (1983), Organizational Culture And Counter Culture: An Uneasy Symbiosis, Organizational Dynamics, 12 (2), pp 52-64.

Morgan, G., 1997, Images Of Organization, London: Sage Publications

O'Reilley, C. (1989), Corporation, Culture And Commitment: Motivation And Social Control In Organizations, California Management Review, 31, Summer, pp. $9-25$.

Ouchie, W.G. (1981), Theory Z, Reading MA: Addison Wesley

Pascale, R.T. and A.G. Athos (1981), The Art Of Japanese Management, Warner book edition.

Paine, L.S. (1994), Managing For Organizational Integrity, Harvard Business Review ${ }_{1}$ March-April, pp. 106-117.

Peters, T.J. and R.H. Waterman, Jr. (1982), In Search Of Excellence, New York: Harper and Row

Pettigrew, A.M. (1979), On Studying Organizational Culture, Administrative Science Quarterly, 24, pp. 570-581.

Pheysey, D.C. (1993), Organizational Culture: Types And Transformation, London: Routledge

Poepowardojo, S. (1989), Strategi Kebudayaan: Suatu Pendekatan Filisofis, Jakarta: Gramedia 
Reger, R.K; J.V. Mullane; L.T. Gustafson and S.M. DeMarie, 1994, Creating Earthquake To Change Organizational Mindsets: Executive Summary, The Academy Of Management Executive, pp.31-45

Reichers, A.E. and B. Schneider (1990), Climate And Culture: An Evolution Of Construct, in B. Schneider (ed) Organizational Climate and Culture, Jossey Bass Publishers

Reynolds, P.D. (1986). Organizational Culture As Related To Industry, Position And Performance: A Preliminary Report, Jurnal Of Management Studies, 23, pp. 333-345

Riley, P. (1983), A Structurationist Account Of Political Cultures, Administrative Science Quarterly, 28, pp.414-437.

Robbins, S.P. (1996), Organizational Behavior: Concept, Controversies And Applications, $7^{\text {th }}$ Edition, Englewood Cliffs, NJ: Prentice Hall Inc.

Rokeach, M. (1973), The Nature Of Human Values, New York: The Free Press.

Rousseau, D. (1990), Assessing Organizational Culture: The Case For Multiple Methods, in B. Schneider (ed.) Organizational Climate And Culture, Jossey Bass Publishers. pp. 153-192.

Sathe, V. (1985), Culture And Related Corporate Reality, Homewood, III: Richard D. Irwin.

Schein, E.H. (1983), The Role Of The Founder In Creating Organizational Culture, Organizational Dynamics, 12 (1), pp13-28.

Schein, E.H. (1984), Coming To A New Awareness Of Organizational Culture, Sloan Management Review, Vol. 25. No 2 pp. 3-16

Schein, E.H. (1985), Organizational Culture And Leadership, San Fransisco: Jossey-Bass.

Schein, E.H. (1990), Organizational Culture, American Psychologist, February, pp. 109-119

Schneider, B. (1990), Organizational Climate and Culture ${ }_{1}$ San Fransisco: Jossey-Bass.

Schneider, S. and J. Barsoux (1997), Managing Across Culture, Prentice Hall Inc.

Schultz, M. and M.J. Hatch (1996), Living with Multiple Paradigm: The Case of Paradigm Interplay in Organizational Culture Studies, Academy of Management Review, April, Vol. 21 no. 2. Pp. 529-557 
Seagall, M.H., P.R. Dansen, J.W. Barry and Y.H. Portinga (1990), Human Behavior In Global Perspective: An Introduction To Cross Cultural Psychology, New York: Pergamon Press.

Siehl, C. and J. Martin (1990), Organizational Culture: A Key To Financial Performance? In Ben Schneider (Ed.) Organizational Climate And Culture, San Francisco: Jossey-Bass Publishers.

Smircich, L. (1983), Concept Of Culture And Organizational Analysis, Administrative Science Quarterly, 28, pp. 339-358.

Thusman, M.L. and C.A. O'Reilly III, 1997, Winning Through Innovation, Boston Ma: Harvard Business School Press.

Wilkin, A.L. and W.G. Ouchie (1983), Efficient Culture: Exploring The Relationship Between Culture And Organization Performance, Administrative Science Quarterly, 28, 468-481

Williams Jr., R. (1979), Change And Stability In Values And Value Systems: A Sociological Perspective, In M. Rokeach (Ed.) Undestanding Human Values, Free Press, pp. 15-46. 